\title{
Extraction and Estimation of Plant Pigments of Medicinal Plants Used in Digestive Problems in Assam
}

\author{
Dr. Minuara Begum*1 ${ }^{1}$ Plabita Bora ${ }^{2}$ \\ ${ }^{I}$ Associate Professor, Division of Phytochemistry, Department of Botany, D.K.D.College, Dergaon-785614, \\ Assam, India \\ ${ }^{2}$ Research Fellow, Institutional Biotech Hub, D.K.D. College, Dergaon-784614, Assam, India
}

*Corresponding Author: Dr. Minuara Begum, Associate Professor, Division of Phytochemistry, Department of Botany, D.K.D.College, Dergaon-785614, Assam, India

\begin{abstract}
Plant pigments not only impart a characteristic color to the particular tissue or organ of leaves or stem but also involved in trapping light for photosynthesis and several other physiological processes. Various pigments are found in plants of which chlorophylls are the most important and take part in the light induced metabolic activities of the plants. Plant pigments benefits the body in a unique and distinctive ways. A recommended and regular intake of plant pigments in the form of herbal extract can keep the digestive system much healthier. It also provides nutrients to the human body. In the present study the pigments were extracted from the leaves of 11 selected medicinal plants and to analyze the presence or absence of different phytochemicals in the herbs used traditionally to cure digestive problems in Assam. It was observed that Eclipta Alba possesses higher pigments than the other tested medicinal herbs. Psidium guajava and Punica granatum shows the presence of phytochemicals.
\end{abstract}

Keywords: Plant pigments, Phytochemicals, Eclipta Alba, Psidium guajava, Punica granatum

\section{INTRODUCTION}

The medicinal plants are being therapeutically exploited throughout the world for treating various ailments and it is the oldest and the safest method to manage or cure illness. The use of herbal drug is as old as human beings [1]. In recent times, focus on plant research has increased all over the world to high light the immense potential of medicinal plants used in various traditional system of medicine. A recommended and regular intake of natural plant pigments in the form of herbal extract can keep the digestive system much healthier. It also provides nutrients to the human body. Plant pigments not only impart a characteristic color to the particular tissue or organ of leaves or stem but also involved in trapping light for photosynthesis and several other physiological processes. Various pigments are found in plants of which chlorophylls are the most important and take part in the light induced metabolic activities of the plants. Chlorophyll benefits the body in a unique and distinctive ways.

In fact, the potential health benefit of a diet rich in chlorophylls have been indicated in recent studies reporting their role as agents preventing some diseases. Therapeutic properties of chlorophylls have been well documented [21].Chlorophyll Stimulates immune system, benefits against sinusitis, fluid buildup, skin rashes and ability to help combat anemia. It also eliminates molds in the body by purifying the blood and detoxifies the liver. It cleans the intestines and rejuvenates and energizes the body.

Chlorophyll is an asymmetric molecule having a hydrophilic head (porphyrin) made up of four substituted pyrrolic rings located around a divalent magnesium $\left(\mathrm{Mg}^{++}\right)$which is complexed with four nitrogen atoms of pyrrole rings(one nitrogen atom from each ring) and a long tail formed by a hydrophobic isoprenoid chain (phytol tail) with a phytol alcohol and 20 carbon atoms.

Two types of chlorophyll; chlorophyll- a and chlorophyll- $b$ are present in terrestrial plants. The difference between these two chlorophyll is a methyl moiety in chlorophyll- a replaced by formyl group in chlorophyll- $b$. The ratio of chlorophyll- a to chlorophyll- $b$ in higher plants is approximately $3: 1$. Chlorophyll absorbs the light mainly in the red $(650-700 \mathrm{~nm})$ and the blue violet $(400-500 \mathrm{~nm})$ 
regions of the visible spectrum. Green light $(550 \mathrm{~nm})$ is not absorbed but reflected giving chlorophyll its characteristics color. Chlorophyll a possesses a green- yellow color [2].

The phytochemical analysis of the plants is very important commercially and has great interest in pharmaceutical companies for the production of the new drugs for curing of various diseases[23].In Assam, some medicinal plants are generally used to cure digestive problems, out of which Alterananthera sessilis, Centella asiatica, Eclipta alba, Houttuynia cordata, Leucas aspera, Mentha arvensis, Paederia foetida, Phyllanthus niruri, Pogostemon benghalensis, Psidium guajava, Punica granatum and Oxalis corrniculata were selected for the present studies.

Alterananthera sessilis commonly called as Sessile Joyweed and Dwarf Copperleaf belonging to the family Amaranthaceae. As an herbal medicine, the plant has diuretic, cooling, tonic and laxative properties. It is used to treat some diseases such as dysuria and haemmorrhoids [3]. Different communities of Utrakhannada district of Karnataka use the plant to treat ulcers, cuts and wounds. The trula tribals of kalavai, Vellore district, Tamilnadu, India, use this plant to treat headache, hepatitis A, asthama [4].

Centella asiatica is a very important medicinal herb used in the orient [5], commonly known as Gotu kola, Mandukpanni or Indian Pennywort or Jalbrahmi. It has been used as a medicine in the Ayurvedic traditions of India for thousands of the years and listed in the historic "Sushruta Samhita" an ancient Indian medical Text [6,7]. Centella asiatica was recommended for the treatment of wound, leprosy, lupus, varicose ulcers, eczema, psoriasis, diarrhea, fever, amenorrhea and diseases of female genitourinary tract [8].

Eclipta Alba Hassk is belonging to the family Asteraceae, commonly available throughout India, common in areas of upper Gangetic plains, in pasture lands, roadsides in Chota, Nagpur, all districts of Bihar and Orissa, Punjab, western India, south India [9]. Eclipta Alba plays an important role in the traditional Ayurvedic, Unani systems of holistic health an herbal medicine of the east. It is reported that Eclipta Alba Hassk possesses hepatoprotective, antimicrobial, antiinflammatory, analgesic, immunomodulatory, antiviral and promoter for blackening and growth of hair [10].

Houttuynia cordata Thumb is belonging to the Saururaceae family, is a flowering and perennial plant. Houttuynia cordata is a well known traditionally used medicinal plant in the indigenous system of medicine of Southeast Asia. Recently several studies reported that Houttuynia cordata is having anti- inflammatory, anti-allergic, virucidal, antilukemic, anti-oxidative and anti- cancer activities. In India, the shoot is used for the freshness, good sleep, heart disorders by Apatani, who have traditionally setteled in seven villages in the Ziro Valley of lower Subansiri district of Arunachal Pradesh in the Eastern Himalayan region of India [11].

Leucas aspera commonly known as Thumbai, Gumma is found all over India. The plant is used for the treatment of many diseases such as cough, cold, diarrhea, inflammatory diseases. It is reported that the plant is having anti-inflammatory, analgesic, ant diarrheal, antimicrobial, antioxidant, insecticidal activities [12].

Mentha arvensis Linn is one such herb belonging to the family Lamiaceae that is a common edible and aromatic perennial herb cultivated throughout India. It is widely used in pharmaceutical, cosmetic and flavoring industries [9].

Paederia foetida is commonly known as "Gandhavadulia" belonging to the family Rubiaceae. The whole plant is traditionally used in Ayurveda medicine for the treatment of various diseases such as asthma, bowel complaints, diarrhea, diabetes, seminal weakness etc. It is also reported that the plant is used in gout, vesical calculi, diarrhea, dysentery, piles, inflammation of the liver and emetic [13].

Phyllanthus niruri is a small erect annual herb belonging to the family Euphorbiaceae. It is about 30$40 \mathrm{~cm}$ in height [20]. It is basically found in Amazon rainforest and other tropical areas including Southeast Asia, southern India and China [14]. P. niruri has an important role in herbal medicine system such as Indian Ayurveda, Traditional Chinese medicine. The plant has been used in dystentery, influenza, vaginitis, tumor, diabetes, diuretics, jaundice, kidney stones and dyspepsia and it is also useful for treating hepatotoxicity, hepatitis B, hyperglycemias and viral and bacterial diseases [6]. It is also an impotant medicinal plant used as antiviral and hepatoprotective agent. The diuretic, hypotensive and hypoglycaemic effect of $P$. niruri were documented in a human study, showed a significant diuretic effect [15] 
Pogostemon benghalensis is a aromatic plant which belongs to the Lamiaceae. It occurs in open riverine forest and also cultivated in almost all the parts of India, Bangladesh, Sri Lanka, Nepal, Myanmar, Thailand and China [22]. It is reported that the plant possesses antibacterial, antifungal, antitubercular, anti rheumatic etc activities [21].

Psidium guajava is an important medicinal plant basically found in tropical and subtropical countries. It is widely used as food and in folk medicine around the world. It is reported that Psidium guajava is mainly known for its antispasmodic and antimicrobial properties in the treatment of diarrhea and dysentery. This plant is also used extensively as a hypoglycaemic agent. Many studies have demonstrated the ability of this plant to exhibit antioxidant, hepatoprotective, antiallergy, antimicrobial, antigenotoxic, antiplasmodial, cytotoxic, antispasmodic, cardioactive, anticough, antinociceptive, activities [16].

Punica granatum commonly known as pomegranate is a member of the family Punicaceae, mainly found in Iran, the Himalayas in the northern India, China, USA and throughout the Mediterranean region extensively [17]. The fruit of Punica granatum has been used extensively as a traditional remedy against acidosis, helminth infection, dysentery, microbial infections, diarrhea, hemorrhage and respiratory pathologies. The seed contains estrogenic compounds, estrone and estradial [18]. Punica granatum possesses inhibitory effects on different types of cancer such as prostate, breast, colon, lung cancers. It inhibits angiogenesis which is an important process for the development of new blood vessels that supply oxygen and nutrition for tumor growth and progression of cancer [17].

Oxalis corriculata Linn, Commonly known as creeping wood sorrel belonging to the family Oxalidaceae is one of the most focus plant species in India. The plant has been used in Indian System of Medicine (ISM) for the treatment of diseases and ailments of human beings. It has been reported that the plant contains anti inflammatory, anticonvulsant, antifungal, antiulcer, anti diabetic, hepatoprotective, antioxidant and diuretic, antimicrobial and wound healing properties [19].

\section{MATERIALS AND MeTHODS}

\subsection{Collection of plants}

The medicinal plants include Alterananthera sessilis, Centella asiatica, Eclipta alba, Houttuynia cordata , Leucas aspera, Mentha arvensis, Paederia foetida, Phyllanthus niruri, Pogostemon benghalensis, Psidium guajava, Punica granatum and Oxalis corrniculata were collected from the herbal garden of DKD College, Dergaon, Assam, India.

\subsection{Extraction of plant pigment: (Arnon, 1949)}

The materials of each collected plant cleaned by removing soil and allowed to air dried and allowed to store for preservation in petri plates for specific room temperature. The estimation was done as per Arnon method. One gram of finely cut fresh leaves were taken and ground with $20 \mathrm{ml}$ of $80 \%$ chilled acetone with the help of mortar and pestle in dark. A pinch of $\mathrm{MgCO}_{3}$ powder added. The extract filtered through Whatman No.1 filter paper. It was then centrifuged at $5000 \mathrm{rpm}$ for 10 minutes. The supernatant was transferred and the procedure was repeated till the residue becomes colorless. The absorbance of the solutions was done at 420-660 nm against the solvents (acetone) blanks.

The dried plant powder was taken in a test tube and distilled water was added in such a way so that the plant powder soaked in it and shaken well. The solution then filtered with the help of filter paper and filtered extract of the selected plant samples were taken and used for further phytochemical analysis.

\section{RESULT AND DISCUSSION}

After conducting the experimental works it was observed that all the herbal medicinal plants shows significant variation in total chlorophyll amount with maximum and minimum values. The light plays a significant role in this chlorophyll estimation. The amount of chlorophyll is changes in different herbs due to light effect. Leaves morphology, total leaves area, growing condition of the plant and illumination of photo period may be the reasons for the variation of chlorophyll concentration in different absorbance of wavelengths.(Table:1) 
Table1. Estimation of Plant Pigments in Medicinal plants

\begin{tabular}{|c|c|c|c|c|c|c|c|c|c|c|c|}
\hline $\begin{array}{l}\text { Sl } \\
\text { no }\end{array}$ & Plants & $\begin{array}{c}40 \\
\text { nm }\end{array}$ & $\begin{array}{l}430 \\
\text { nm }\end{array}$ & $\begin{array}{l}500 \\
\mathbf{n m}\end{array}$ & $\begin{array}{l}520 \\
\text { nm }\end{array}$ & $\begin{array}{l}540 \\
\mathrm{~nm}\end{array}$ & $\begin{array}{l}\mathbf{5 8 0} \\
\mathbf{n m}\end{array}$ & $\begin{array}{l}600 \\
\mathrm{~nm}\end{array}$ & $\begin{array}{l}620 \\
\mathrm{~nm}\end{array}$ & $\begin{array}{l}680 \\
\text { nm } \\
\end{array}$ & Total \\
\hline 1 & Alternanthera sessilis & 2.29 & 2.31 & 1.01 & 0.79 & 0.80 & 1.16 & 1.49 & 1.23 & 2.42 & 13.5 \\
\hline 2 & Centella asiatica & 1.0 & 1.0 & 0.65 & 0.58 & 0.56 & 1.01 & 1.64 & 1.23 & 2.44 & 10.11 \\
\hline 3 & Houttuynia cordata & 1.54 & 1.0 & 0.80 & 0.65 & 0.65 & 0.61 & 0.80 & 0.87 & 1.62 & 8.54 \\
\hline 4 & Eclipta alba & 1.49 & 2.37 & 2.69 & 2.07 & 1.86 & 1.74 & 2.95 & 1.37 & 4.17 & 20.71 \\
\hline 5 & Leucas aspera & 1.84 & 1.86 & 0.80 & 0.64 & 0.78 & 0.85 & 1.12 & 1.41 & 1.24 & 10.54 \\
\hline 6 & Mentha arvensis & 1.0 & 1.0 & 1.34 & 1.05 & 1.0 & 1.07 & 1.71 & 1.30 & 2.52 & 11.99 \\
\hline 7 & Phyllanthus niruri & 1.12 & 1.26 & 1.05 & 0.97 & 1.08 & 1.12 & 1.46 & 1.28 & 2.40 & 11.74 \\
\hline 8 & Pogostemon benghalensis & 2.31 & 1.16 & 1.07 & 1.08 & 1.11 & 1.83 & 1.26 & 1.29 & 2.30 & 13.41 \\
\hline 9 & Psidium guajava & 1.36 & 1.92 & 1.86 & 1.22 & 1.07 & 0.82 & 1.04 & 0.72 & 1.08 & 11.09 \\
\hline 10 & Punica granatum & 1.06 & 1.22 & 0.84 & 0.68 & 0.63 & 0.73 & 1.01 & 1.03 & 1.86 & 9.06 \\
\hline 11 & Oxalis corniculata & 1.29 & 1.81 & 0.68 & 0.48 & 0.40 & 0.27 & 0.30 & 0.26 & 0.27 & 5.76 \\
\hline
\end{tabular}

The presence of primary and secondary metabolites also plays an important role in proving the therapeutic uses of these medicinal plants in curing various diseases specially in digestive as well as stomach ailments.(Table:2).

Table2. Preliminary Phytochemical Screening of Medicinal plants

\begin{tabular}{|l|l|l|l|l|l|l|}
\hline Sl no & \multicolumn{1}{|c|}{ Plants } & Carbohydrates & \multicolumn{1}{|c|}{ Protein } & \multicolumn{1}{c|}{ Oil } & \multicolumn{1}{c|}{ Phenol } & \multicolumn{1}{c|}{ Anthocyanin } \\
\hline 1 & Alternanthera sessilis & + & Trace & - & + & Trace \\
\hline 2 & Centella asiatica & + & - & ++ & ++ & - \\
\hline 3 & Houttuynia cordata & + & ++ & ++ & + & Trace \\
\hline 4 & Eclipta alba & - & Trace & Trace & +++ & Trace \\
\hline 5 & Leucas aspera & - & Trace & Trace & ++ & + \\
\hline 6 & Mentha arvensis & Trace & + & ++ & ++ & ++ \\
\hline 7 & Phyllanthus niruri & ++ & +++ & - & +++ & + \\
\hline 8 & Pogostemon benghalensis & - & + & ++ & + & + \\
\hline 9 & Psidium guajava & +++ & +++ & - & +++ & +++ \\
\hline 10 & Punica granatum & ++ & ++ & + & +++ & +++ \\
\hline 11 & Oxalis corniculata & Trace & ++ & - & ++ & Trace \\
\hline
\end{tabular}

N.B: $\quad+++=$ Abundance; ++=Average; += Mild; - = Absence.

\section{CONCLUSION}

Usually medicinal plants contain chlorophyll pigments and several phytochemical compounds which are very much necessary to combat the various diseases of human beings. The research conducted on these herbs has shown its traditional uses for a wide variety of diseases in India. Some of the medicinal usages have been proven in experimental models, which suggest that the extracts of the plant possess various pharmacological actions. Owing to the impressive preclinical therapeutic potential, the plant extracts have been evaluated in human trials for the treatment of digestive diseases. The phytochemicals exhibited different structural characteristics. More importantly, there have been no side effects or toxicity reports on these herbs. Although there have been extensive researches on this herbs, there are still a lot of scopes for further researches, especially towards the mechanism of biological activity of phytochemicals. The studies are expected to lead the way in the discovery of new agents with improved pharmacological properties.

It is expected that the important phytochemical properties recognized by this study on the traditional herbal medicinal plants of Assam is very useful in the curing of various digestive diseases of this regions.

\section{ACKNOWLEDGEMENT}

The authors are thankful to the Principal, D.K.D. College and Department of Botany and Institutional Biotech Hub (IBH) for providing necessary research facilities and technical support.

\section{REFERENCES}

[1] Saleem M.N., Mohammad I., Podina (Mentha arvenis): Transformation from food additive to multifunctional medicine. ARC Journal of Pharmaceutical sciences, volume 2, Issue2, PP6-15 ISSN245-1538(2016).

[2] Arnon D.I., Copper enzyme polyphenoloxides in isolated chloroplast in Beta vulgaris. Plant Physiology. 24:115(1949). 
[3] Sravani V.L., Zarafsha A., Pallati S., A Review on Alternanthera sessilis. Indo American Journal of Pharmaceutical Sciences., ISSN-2349-7750(2017).

[4] Ahmed H.I., Mohammad F., Rahman S., Rownak J. and Mohammad R. , A Preliminary Evaluation of Antihyperglycemic and Analgesic activity of Alternanthera sessilis aerial parts;//www.ncbi.nlm.nih.gov/pmc/articles/PMC4035668/

[5] Bown D., Encyclopedia of Herbs and their Uses. London: Dorling Kindersley. P361-5(1995).

[6] Chopra R.N., Nayar S.L., Chopra I., Glossary of Indian Medicinal Plants (Including the Supplement). New Delhi: Council of Scientific and Industrial Research. P.51-83(1986).

[7] Diwan P.C., Karwande I., Singh A.K., Anti-anxiety profile of Mandukparni Centella asiatica Linn in animals. Fitoterapia, 62:255-7(1991).

[8] Brinkhaus B., Linder M., Schuppan D., Hahn E.G., Chemical, Pharmacological and clinical profile of the East Asian medical plant Centella asiatica. Phytomedicine, 7:427-48(2000).

[9] Sharma P.C., Yelne M.B. and Denn's T.J., Database on medicinal plants used in Ayurveda. Vol-2, Central council for research in Ayurveda and Siddna, New Delhi, 112(2001).

[10] Jadhav V.M., Thorat R.M., Kadam V.J., and Sathe N.S., Eclipta Alba Linn- "Kesharaja”: A Review. Journal of Pharmacy Research.2 (8),1236-1241, ISSN:0974-6943(2009).

[11] Jiangang Fu., Ling Dai., Zhang Lin., Hongmei Lu., Houttuynia cordata Thunb: A Review of Phytochemistry and Pharmacology and Quality Control. Chinese Medicine.4, 101-123(2013).

[12] Gulnaaz S., Vimala Y., Leucas Aspera: Medicinal Plant Review. International Research Journal of Multidisciplinary Studies. ISSN: 2454-8499(2015).

[13] Chauhan K., Patel A., Patel M., Macwan C., Solanki R., Adeshara S., Paederia foetida Linn. As a potential medicinal plant: A Review. Journal of Pharmacy Research. ISSN: 0974-6943(2010).

[14] Girach R.D., Siddioui P.A., Khan S.A., Traditional plant remedies among the kondh (Orissa). Int. J. Pharmacol.32:274-283(1994).

[15] Devi M.V., Satyanarayana S., Rao A.S., Effect of Phyllanthus niruri on the diuretic activity of Punarnava tablets. J. Res.Edu. Ind. Med. 5:11-12(1986).

[16] Gutierrez R.M., Sylvia M., Rosario V. S., Psidium guajava: A review of its traditional uses, phytochemistry and pharmacology. Journal of Ethnopharmacology (2008).

[17] Hamid R.R., Mohammad A., Sayed N.O., A Comprehensive Review of Punica granatum(pomegranate) properties in Toxicological, Pharmacological , Cellular, and Molecular Biology Researchers. Iranian Journal of Pharmaceutical Research, 11(2):385-400(2012).

[18] Kim YH., Choi EM., Stimulation of osteoblastic differentiation and inhibition of interlukin-6 and nitric oxide in MC3T3-E1 Cells by pomegranate ethanol extract. Phytother.Res. 23:737-739(2009).

[19] Sharma R.A., Kumari A., Phytochemistry, Pharmacology and Therapeutic Application of Oxalis Corniculata Linn.-A Review. International Journal of Pharmacy and Pharmaceutical Sciences, ISSN-0975-1491(2009).

[20] Bagalkotkar G., Sagineedu S.R., Saad M.S., Stanslas J., Phytochemicals from Phyllanthus niruri Linn. And their pharmacological properties: a review. Journal of Pharmacy and Pharmacology. ISSN 0022-3573(2006).

[21] Shigwan V.A., Khade B.A., Hatpakki C.B., Ghurghure M.S., A Comprehensive Review on Pogostemon benghalensis (Burm.F.)O. Kuntze. Research and Reviews: Journal of Pharmacognosy and Phytochemistry (2013).

[22] Bhuiyan Md. N I , Varshney V.K., Shiam C.V., Arvind T. F., Composition of essential oil of the leaf and inflorescence of Pogostemon benghalensis( Burm.f) Kuntze. Int Res. J. Plant Sci.2 (9):271-5(2011).

[23] Wadood A., Ghufran M., Jamal B. S., Naeem M., Khan A., Ghaffar R., Asnad., Phytochemical Analysis of Medicinal Plants Occurring in Local Area of Mardan. Biochemistry \& Analytical Biochemistry .2:4 DOI:10.4172/2161-1009.1000144 ISSN: 2161-1009(2013).

Citation: M. Begum, P. Bora "Extraction and Estimation of Plant Pigments of Medicinal Plants Used in Digestive Problems in Assam ", ARC Journal of Pharmaceutical Sciences (AJPS), vol. 4, no. 1, p. 12-16, 2018. http://dx.doi.org/10.20431/2455-1538.0401003

Copyright: (C) 2018 Authors. This is an open-access article distributed under the terms of the Creative Commons Attribution License, which permits unrestricted use, distribution, and reproduction in any medium, provided the original author and source are credited 